\title{
The effects of fragmentation on Araucaria forest: analysis of the fern and lycophyte communities at sites subject to different edge conditions
}

\author{
Vinícius Leão da Silva ${ }^{1}$ and Jairo Lizandro Schmitt ${ }^{1+}$
}

Received: October 14, 2014 Accepted: January 30, 2015

\begin{abstract}
Edge effects impact species richness and composition as a result of environmental changes caused by fragmentation. This study analyzed edge effects on a community of terrestrial ferns and lycophytes in an Araucaria forest in Brazil at sites subjected to differing edge conditions: (1) a site bordering a road running through the interior of a conservation unit, and (2) a site bordering an agricultural property. Twelve $10 \times 10 \mathrm{~m}$ plots were selected at the edge and in the interior of each site, and accounted for a total of 48 plots. The edges had lost their characteristic floristic identity, suggesting that many species are sensitive to variations in environmental conditions. The edge effect had a negative impact on species richness as shown by the greater average numbers of fern and lycophyte species in forest interiors at both sites. The results showed that the forest fragments in contact with agricultural areas were subjected to more intense edge effects than the fragments bordering a road within a conservation unit.
\end{abstract}

Keywords: edge effect, environmental change, microclimate, mixed rain forest, soil

\section{Introduction}

Fragmentation of forested areas is one of the most pervasive causes of biodiversity loss and can result in local or total species extinctions (Bierregaard et al. 1992; Turner 1996; Tabarelli et al. 1999). Reduction of forest areas reduces the internal heterogeneity of habitats and their natural resources while increasing the area exposed to edge effects (Murcia 1995; Metzger 1999; Fahrig 2003; Ribeiro et al. 2009). The micro-habitats at the edges of forest remnants are different from their interiors, and some of the most obvious effects are intimately linked to low humidity and increased light intensity, temperature, and wind exposure (Kapos 1989; Murcia 1995). The increased light penetration is the most decisive of these factors because it is directly linked to humidity and temperature (Murcia 1995). Light intensity and wind velocities are both higher at the forest edges because the natural barriers created by adjacent trees are absent (Silva et al. 2010). These factors also increase deposition of litter along the forest edges, rendering plant communities more vulnerable to fires (Laurance et al. 2002).

Studies are investigating edge effects on communities of tree species (Williams-Linera 1990; Laurance et al. 1998; Fontoura et al. 2006). Environmental changes associated with forest edges can have negative impacts on the plant communities that survive in forest remnants, leading to the death of large numbers of trees (Laurance et al. 2000).
There are also few studies describing how other taxonomic groups, including ferns and lycophytes (Paciencia \& Prado 2004; 2005; Barros et al. 2006; Silva et al. 2011; 2014; Pereira et al. 2014) and fruticose lichens (Esseen \& Renhorn 1998) or bryophytes (Baldwin \& Bradfield 2007), respond to these effects.

Different species respond differently to edge effects and the effects themselves do not manifest in exactly the same way at all edges (Paciencia \& Prado 2004). At the time of formation of edges and elimination of sensitive species, increased numbers of pioneer species and species tolerant to the climatic conditions of the changed environment are also observed (Laurance et al. 1998).

Ferns and lycophytes are important groups of vascular plants that reproduce via spores. The Atlantic rainforest is Brazil's richest biome in terms of seedless vascular plants, and approximately $40 \%$ of the fern and lycophyte species that occur in the Atlantic rainforest are endemic to this biome (Forzza et al. 2012). Ferns and lycophytes are considered important indicators of environmental quality, because they are responsive to changes in abiotic factors (Ferrer-Castán \& Vetaas 2005; Silva et al. 2011) such as humidity (Windisch 1992) and light availability (Sharpe \& Mehltreter 2010).

Grime (1985) demonstrated that many species of ferns and lycophytes are unable to resist the climatic changes caused by edge effects, because they are sensitive to the

\footnotetext{
${ }^{1}$ Programa de Pós-Graduação em Qualidade Ambiental, Universidade Feevale, ERS 239, 2755, 93352-000, Novo Hamburgo, RS, Brazil

*Corresponding author: jairols@feevale.br
} 
greater light intensity and wind velocity. Certain species in these groups that inhabit the interiors of forests have very narrow ecological amplitude, being practically excluded by the conditions of some microhabitats, and it has been shown that they are highly sensitive to environmental changes (Senna \& Kazmirczak 1997) caused by fragmentation. In Brazil, Paciencia \& Prado $(2004 ; 2005)$ and Silva et al. $(2011 ; 2014)$ conducted comparative analyzes of edges and interiors of rainforests in northeastern Brazil and found that the species richness of ferns and lycophytes was reduced in edges when compared with sites in the forest interior. The edge effect can result in substitution of more sensitive species by those that are more tolerant to the impacts caused by fragmentation, resulting in impoverishment and decharacterization of the local native flora (Pereira et al. 2014).

The objectives of this study were to as follows: (1) compare the coverage, richness, and composition of terrestrial fern and lycophyte communities in the interior and at the edge of two sites in Araucaria forest, (2) compare microclimatic conditions between the edges and interiors of the sites, (3) analyze the influence of openings in the canopy, litter depth, and soil moisture content on the distribution of plant richness and coverage, and (4) compare the site that is bordered by a road with the site that has an adjacent agricultural property, in terms of the biotic and abiotic variables. Three hypotheses were tested: (1) species richness and coverage decrease in the forest edge, (2) vegetation, soil, and microclimate variables change between the edge and forest interior, and (3) the existence of an edge effect varies according to the type of habitat edge.

\section{Material and methods}

This study was conducted in a national forest located in the municipality of São Francisco de Paula (FLONA-SFP), Rio Grande do Sul, southern Brazil. The FLONA-SFP covers an area of 1,606.60 ha and comprises a mosaic of Araucaria forest and plantations of exotic and native species (Silva et al. 2010). The Araucaria forest is extremely fragmented and occurrence is restricted to the south and southeastern regions of Brazil. The distribution of this forest type has been reduced to less than 5\% of the original area (MMA/ SBF 2002).

The study area comprised part of the Araucaria forest, in which the dominant species is Araucaria angustifolia (Bertol.) Kuntze. The climate of the study area can be described as humid temperate, with a temperate summer (Cfb) (Moreno 1961) and mean annual temperature and rainfall of $14.1^{\circ} \mathrm{C}$ and $2,468 \mathrm{~mm}$, respectively. The soil is classified as humose aluminous cambisol, from shallow to deep, combined with lytholic entisol, rich in organic material, and common in areas with high rainfall and low temperatures (Streck et al. 2008). Two sites in the area were selected for the analysis of edge effects. The sites were 3.6 $\mathrm{km}$ apart, protected from cattle grazing, and were not sub- ject to the passage of fire. The first site, Macaco Branco, is located in a part of the forest where edges have been created by construction of a road that is approximately $10 \mathrm{~m}$ wide and cuts through the interior of the conservation unit $\left(29^{\circ}\right.$ $25^{\prime} 08^{\prime} \mathrm{S}$ and $\left.50^{\circ} 23^{\prime} 44^{\prime} \mathrm{W} 960 \mathrm{~m}\right)$. The Macaco Branco site suffered processes of fragmentation due to clearance for construction of the road and to obtain trees for lumber. The second site, Cravina, is located in a part of the same forest with an edge bordering an agricultural property that is outside of the FLONA-SFP $\left(29^{\circ} 26^{\prime} 51^{\prime} \mathrm{S}\right.$ and $50^{\circ} 22^{\prime} 50^{\prime} \mathrm{W}$ $918 \mathrm{~m}$ ). Between the 1940s and 1970s, as the population of Araucaria was exhausted, cultivation of crops and Pinus plantation replaced the natural forest.

A total of 25 points, $10 \mathrm{~m}$ apart were marked along a $250 \mathrm{~m}$ extent of the edge of each site, following which 12 of these points were randomly selected at each site. At each point, a $10 \times 10 \mathrm{~m}$ plot was marked at $5 \mathrm{~m}$ into the edge of the forest fragment. Another sampling plot of the same size was marked out $100 \mathrm{~m}$ into the forest, parallel to each of the edge plots. Therefore, 12 sampling points were selected at the edge of each site and 12 were selected in the interior of each site, accounting for a total of 48 plots.

For each plot, all species of terrestrial ferns and lycophytes were recorded and their coverage area was measured with measuring tape. Taxonomic identifications were accomplished using specialist bibliographic references, by comparison with specimens deposited in a herbarium and by consultation with specialists. Plant families were organized according to Smith et al. (2006; 2008). Representative fertile specimens were collected and deposited in the Herbarium Anchieta (PACA), at the Universidade do Vale do Rio dos Sinos, São Leopoldo, Rio Grande do Sul, Brazil.

Air temperature, relative air humidity, and wind velocity were recorded on one day in summer and one day in winter at hourly intervals during a period of 12 consecutive hours (from $6 \mathrm{~h}$ to $18 \mathrm{~h}$ ) at the edge and in the interior of the site. To achieve this, a portable digital thermo-hygro-anemometer (Instruterm-Thal-300, model 0211) was mounted on a 0.75 m high tripod (VF WT-3111). On the same day, hemispheric photos were taken at the edges and interiors of the sites from the center of each plot, for determination of the proportion of the canopy that was open. These areas were photographed using a Sony H5 camera fitted with a Raynox Digital fish eye lens, model DCR-CF 85 Pro, which had been leveled and aimed north (Garcia et al. 2007), at $1 \mathrm{~m}$ from the ground. The images were later analyzed using GAP Light Analyzer version 2.0 software to obtain the percentage of the canopy that was open (Frazer et al. 1999).

Soil moisture and depth of the litter layer were also measured at three points within each plot on the same days during summer and winter. Soil moisture content was measured using an AT Delta-T Device HH2 version 4.0 Moisture Meter. Litter depth (in $\mathrm{cm}$ ) was measured using a rule with a millimeter scale. 
The Shapiro-Wilk test was used to verify the normality of the biotic and abiotic data from the interior and edges. Since the hypothesis of normality was ruled out, data were compared using the Mann-Whitney nonparametric test (U), to $5 \%$ probability. These analyzes were conducted using Biostat 5.0 statistical software.

The presence and absence data of ferns and lycophytes species at both sites were subjected to Principal Coordinates Analysis. A Principal Component Analysis (variancecovariance matrix) was performed with litter $(\mathrm{cm})$, soil moisture (\%), area of open canopy (\%), and richness and coverage (\%) of fern and lycophyte species in the 48 plots to verify the segregation between the sites and to identify the variables most strongly correlated to the groups. This analysis was performed using the PAST software, version 2.17 (Hammer et al. 2001).

\section{Results}

We identified a total of 32 species of ferns and one lycophyte, distributed across 23 genera and 15 families. The family with greatest richness was Dryopteridaceae (six species), followed by Aspleniaceae and Thelypteridaceae, with four species each, and Blechnaceae and Polypodiaceae with three species each. The Macaco Branco site had greater richness ( 30 species), with 16 species at the edge and 27 in the forest interior. At the Cravina site, total richness was 14 species, with seven recorded at the edge and 11 in the interior. Comparison of richness at the edge and in the interior of the Macaco Branco site revealed 13 species in common, whereas at the Cravina site, only four species occurred both at the edge and in the interior. Considering the total number of species inventoried, the interior Macaco Branco site accounted for $91 \%$ of total species richness (Tab. 1).

Table 1. Families and species of ferns and lycophytes recorded in two sites of an Araucaria forest in southern Brazil. Cra: Cravina site; MB: Macaco Branco site; In: Interior.

\begin{tabular}{|c|c|c|c|c|c|}
\hline \multirow{2}{*}{ Families/Species } & \multicolumn{2}{|c|}{ Cra } & \multicolumn{2}{|c|}{ MB } & \multirow{2}{*}{ MDH (PACA) } \\
\hline & Edge & In & Edge & In & \\
\hline \multicolumn{6}{|l|}{ ANEMIACEAE } \\
\hline Anemia phyllitidis (L.) Sw. & & & 2 & 2 & 114721 \\
\hline \multicolumn{6}{|l|}{ ASPLENIACEAE } \\
\hline Asplenium claussenii Hieron. & & & 1 & 22 & 114704 \\
\hline Asplenium gastonis Fée & & & & 2 & 114705 \\
\hline Asplenium harpeodes Kunze & & 21,5 & & & 114708 \\
\hline Asplenium martianum C.Chr. & & & 1 & 6 & 114711 \\
\hline \multicolumn{6}{|l|}{ ATHYRIACEAE } \\
\hline Diplazium cristatum (Desr.) Alston & & & & 1 & 115159 \\
\hline Deparia pettersenii (Kunze) M.Kato & & & & 2 & 115160 \\
\hline \multicolumn{6}{|l|}{ BLECHNACEAE } \\
\hline Blechnum austrobrasilianum de la Sota & 3 & & & & 114730 \\
\hline Blechnum acutum (Desv.) Mett. & 33 & 42 & 42 & 314 & 114733 \\
\hline Blechnum brasiliense Desv. & 2,5 & & & & 115158 \\
\hline \multicolumn{6}{|l|}{ CYATHEACEAE } \\
\hline Alsophila setosa Kaulf. & & & 2 & & 114741 \\
\hline \multicolumn{6}{|l|}{ DICKSONIACEAE } \\
\hline Dicksonia sellowiana Hook. & & 25 & 22 & 232 & 115156 \\
\hline \multicolumn{6}{|l|}{ DRYOPTERIDACEAE } \\
\hline Ctenitis submarginalis (Langsd. \& Fisch.) Ching & 14,5 & 16 & 1 & 17,5 & 114752 \\
\hline Elaphoglossum sellowianum (Klotzsch ex Kuhn) T. Moore & & & & 2 & 114759 \\
\hline Lastreopsis amplissima (C.Presl) Tindale & & 2 & & 4 & 114761 \\
\hline Megalastrum oreocharis (Sehnem) Salino \& Ponce & 12 & 10 & 5 & 71,5 & 114764 \\
\hline Polystichum platylepis Fée & & 3 & 10,5 & 4 & 114766 \\
\hline Rumohra adiantiformis (G.Forst.) Ching & & & & 1 & 114767 \\
\hline
\end{tabular}


Table 1. Continuation.

\begin{tabular}{|c|c|c|c|c|c|}
\hline \multirow{2}{*}{ Families/Species } & \multicolumn{2}{|c|}{ Cra } & \multicolumn{2}{|c|}{ MB } & \multirow{2}{*}{ MDH (PACA) } \\
\hline & Edge & In & Edge & In & \\
\hline \multicolumn{6}{|l|}{ DENSTAEDTIACEAE } \\
\hline Dennstaedtia dissecta T. Moore & & 2 & & & 114742 \\
\hline Dennstaedtia globulifera (Poir.) Hieron. & & 1 & 1 & 1 & 114744 \\
\hline \multicolumn{6}{|l|}{ HYMENOPHYLLACEAE } \\
\hline Hymenophyllum caudiculatum Mart. & & & 1 & 2 & 114645 \\
\hline \multicolumn{6}{|l|}{ LINDSAEACEAE } \\
\hline Lindsaea botrychyoides A.St.-Hil. & & & 6,5 & & 114747 \\
\hline \multicolumn{6}{|l|}{ MARATTIACEAE } \\
\hline Eupodium kaulfussii (J.Sm.) J.Sm. & & & & 6 & 115154 \\
\hline \multicolumn{6}{|l|}{ POLYPODIACEAE } \\
\hline Campyloneurum minus Fée & & & & 1 & 115157 \\
\hline Campyloneurum nitidum (Kaulf.) C.Presl & & & & 10 & 114661 \\
\hline Pecluma sicca (Lindm.) M.G.Price & & 1 & 2 & 1 & 114662 \\
\hline \multicolumn{6}{|l|}{ PTERIDACEAE } \\
\hline Adiantum raddianum C.Presl & & & & 2 & 115153 \\
\hline Pteris deflexa Link & 16,5 & 17,5 & 8 & 15 & 114682 \\
\hline \multicolumn{6}{|l|}{ SELAGINELLACEAE } \\
\hline Selaginella muscosa Spring & & & & 3 & 115155 \\
\hline \multicolumn{6}{|l|}{ THELYPTERIDACEAE } \\
\hline Thelypteris decurtata subsp. decurtata (Link) de la Sota & & & & 1 & 114694 \\
\hline Thelypteris recumbens (Rosenst.) C.F.Reed & & & 2 & 3 & 114693 \\
\hline Thelypteris riograndese (Lindm.) C.F.Reed & & & & 8,5 & 114692 \\
\hline Thelypteris scabra (C.Presl) Lellinger & 8,5 & & & & 115152 \\
\hline TOTAL COVERAGE $\left(\mathbf{m}^{2}\right)$ & 90 & 141 & 107 & 734,5 & \\
\hline TOTAL RICHNESS & 7 & 11 & 16 & 27 & \\
\hline
\end{tabular}

Table 2. Comparison of biotic and abiotic variables between forest edges and interiors of the Macaco Branco and Cravina sites Min: Minimum values; Mean \pm SD: Mean values \pm standard deviation; Max: Maximum values; S: Richness of ferns and lycophytes; CA: Coverage area of ferns and lycophytes: CONO: Proportion of open canopy area; T: Temperature; RH: Relative humidity of air; WV: wind velocity; LITT: Litter depth; MOIS: moisture content of soil; U: Mann-Whitney test; P: $5 \%$ significance

\begin{tabular}{|c|c|c|c|c|c|c|c|c|c|c|c|c|c|c|c|c|}
\hline \multirow{3}{*}{ Parameter } & \multicolumn{8}{|c|}{ Macaco Branco } & \multicolumn{8}{|c|}{ Cravina } \\
\hline & & Edge & & & Interior & & & & & Edge & & & Interior & & & \\
\hline & Min. & Mean \pm SD & Max. & Min. & Mean \pm SD & Max. & $\mathrm{U}$ & $P$ & Min. & Mean \pm SD & Max. & Min. & Mean \pm SD & $\operatorname{Max}$ & $\mathrm{U}$ & $P$ \\
\hline$S\left(\right.$ species plot $\left.^{-1}\right)$ & 1 & $4.0 \pm 1.7$ & 6 & 5 & $8.3 \pm 2.0$ & 11 & 6 & $<0.001$ & 2 & $3.1 \pm 1.1$ & 5 & 3 & $4.3 \pm 1.0$ & 6 & 32 & 0.021 \\
\hline $\mathrm{CA}\left(\mathrm{m}^{2} \mathrm{plot}^{-1}\right)$ & 1 & $9.5 \pm 9.1$ & 36.5 & 41 & $69.1 \pm 16.9$ & 93.5 & 0 & $<0.001$ & 4.5 & $7.75 \pm 3.3$ & 16 & 4 & $12.0 \pm 8.6$ & 33.5 & 27.5 & 0.580 \\
\hline CONO (\%) & 14.5 & $15.3 \pm 1.2$ & 18.1 & 9.5 & $12.6 \pm 2.4$ & 17.8 & 23 & 0.005 & 15.6 & $18.8 \pm 2.3$ & 23.7 & 7.1 & $12.3 \pm 4.5$ & 23.7 & 14 & 0.001 \\
\hline $\mathrm{T}\left({ }^{\circ} \mathrm{C}\right)$ & 6.5 & $18.6 \pm 5.5$ & 25.1 & 5,6 & $18.8 \pm 5.5$ & 26.6 & 284 & 0.943 & 8.2 & $20.2 \pm 4.8$ & 26.5 & 6.4 & $18.9 \pm 5.0$ & 24.8 & 238 & 0.303 \\
\hline RH (\%) & 51.1 & $72.9 \pm 10.9$ & 90.7 & 48 & $72.5 \pm 10.8$ & 89 & 288 & 1.000 & 39.1 & $59.7 \pm 9.6$ & 75.2 & 50.7 & $68.5 \pm 7.3$ & 80 & 131.5 & 0.001 \\
\hline WV $(\mathrm{km} / \mathrm{h})$ & 0 & $0.4 \pm 0.8$ & 2.6 & 0 & $0.4 \pm 0.7$ & 2.4 & 280 & 0.869 & 0 & $4.2 \pm 3.7$ & 12.1 & 0 & $0.7 \pm 1.0$ & 3.3 & 74 & $<0.001$ \\
\hline LITT (cm) & 1.5 & $4.6 \pm 1.6$ & 8.5 & 1 & $3.1 \pm 1.1$ & 6 & 1113.5 & $<0.001$ & 2 & $4.8 \pm 1.5$ & 9 & 0 & $2.6 \pm 1.2$ & 6 & 656 & $<0.001$ \\
\hline MOIS (\%) & 0.4 & $21.3 \pm 6.8$ & 34.5 & 8.4 & $32.7 \pm 13.6$ & 75 & 1298.5 & $<0.001$ & 3.5 & $23.6 \pm 9.3$ & 47 & 8.6 & $30.5 \pm 7.6$ & 45.4 & 1372.5 & $<0.001$ \\
\hline
\end{tabular}


At the Macaco Branco site, mean species richness in the interior was twice that recorded at the edge. The interior of the Cravina site similarly had greater richness than the edge. The results for richness of ferns and lycophytes per plot were statistically non-significant at the edges of both sites ( $\mathrm{U}=48, P=0.165)$, but species richness of their interiors were highly significant $(\mathrm{U}=5, P=0.001)$. The mean species richness per plot in the interior at Macaco Branco was also twice the richness in the interior at Cravina. A single plot in the interior at the Macaco Branco site had 11 species, which is almost two-fold that of the highest number found in edge plots at this site and the maximum in both edge and interior plots at the Cravina site (Tab. 2).

Out of all the environments analyzed, the largest average species coverage area per plot was observed in the interior of the Macaco Branco site. In comparison with the edge of the same site, interior coverage was six-fold larger. The interior at Macaco Branco also had a significantly larger mean area than the interior at Cravina $(\mathrm{U}=0, P<0.001)$. However, a comparison between areas at the forest edges did not show any difference $(\mathrm{U}=69, P=0.862)$, and the same result was observed after comparison of the plant coverage at the edge and in the interior at Cravina (Tab. 2).

At both sites, the canopy cover was significantly greater in the interiors than at the edges (Tab. 2). There was greater canopy cover at the edge of the Macaco Branco site than at the edge at the Cravina site $(\mathrm{U}=12, P=0.0005)$ but no difference between the canopies in the interiors of the sites $(\mathrm{U}=64, P=0.644)$.

The mean temperatures for edges and interiors were statistically equal at the two sites. A comparison of edges with interiors ( $\mathrm{U}=241, P=0.332$ ) also failed to detect differences $(\mathrm{U}=282.5, P=0.909)$. Wind velocity was significantly different only between the edge and the interior at Cravina. At the edge of this site, the maximum velocity reached $12.1 \mathrm{~km} / \mathrm{h}$. Wind velocity at the Macaco Branco edge was significantly lower than that at the Cravina edge ( $\mathrm{U}=48.5, P=0.0001)$. A similar significant difference in relative air humidity was found only between the edge and interior at Cravina, with higher air moisture in the interior (Tab. 2). The air was drier at the Cravina edge than that at the Macaco Branco edge $(\mathrm{U}=110$, $P=0.0002)$. No differences in air humidity $(\mathrm{U}=204.5$, $P=0.085)$ or wind velocity $(\mathrm{U}=228, P=0.216)$ were observed between the forest interiors at the two sites.

At Macaco Branco, the soil was drier and the litter layer was deeper at the edge, and the same was observed at the Cravina site. The highest absolute humidity was measured in the forest interior at Macaco Branco (Tab. 2). Mean soil moisture at edges $(\mathrm{U}=2201, P=0.118)$ and in interiors $(\mathrm{U}=2349, P=0.332)$ did not differ significantly between sites. There was also no difference between edges at the two sites in terms of mean depth of the litter layer $(\mathrm{U}=2410.5$, $P=0.468)$. In contrast, comparison of litter depth in the interiors revealed that the litter layer at Macaco Branco was deeper than that at Cravina $(\mathrm{U}=1906, P=0.006)$.
The Principal Coordinates Analysis (PCoA) grouped the plots in the interior of the Macaco Branco site separately from the plots at the edge, providing evidence of a heterogeneous floristic composition. For the Cravina sites, our analysis demonstrated an overlap of edge and interior plots which were grouped together. This site therefore had a more uniform floristic composition, exhibiting greater similarity between the edge and interior (Fig. 1).

The Principal Components Analysis (PCA) demonstrated that components 1 and 2 explained $98.38 \%$ of variation. This analysis provides evidence for a direct relationship between the species richness of terrestrial ferns and lycophytes and soil moisture and coverage by vegetation. The plots where soil humidity was greatest, the litter layer was shallowest, and the canopy cover was greatest, exhibited the greatest richness and coverage of plants (Fig. 2).

\section{Discussion}

The edge effect had a negative impact on species richness of ferns and lycophytes, with greater mean richness in the understories of the interiors of both fragments. Nevertheless, it was observed that the edge effect was stronger in Cravina, where the species richness reduced to half, compared with Macaco Branco, suggesting that an agricultural matrix enhances the edge effect. The current study therefore provides further evidence supporting the findings of Paciencia \& Prado (2004), Silva et al. (2011), and Silva et al. (2014), indicating that ferns and lycophytes are potentially vulnerable to edge effects.

In the forest interior, the high level of soil moisture, combined with the thinner litter layer and greater proportion of canopy cover, are factors that favor the occurrence of greater richness of ferns and lycophytes at both sites. Their gametophytes are small and ephemeral, flat and green, and most grow in substrates above the soil level, rather than directly in the soil, to facilitate light absorption (Sharpe \& Mehltreter 2010). In contrast, the deeper litter layer at the forest edges, under direct exposure to greater light intensities, faster winds and lower humidity, would decompose at a slower rate because of the lower humidity, and would consequently accumulate more than in the interior (Portela \& Santos 2007).

At both sites, the forest edges had deeper litter layers. A thicker build-up of litter can increase susceptibility to fires by concentrating biomass at forest edges (Laurance et al. 2002). This element, in combination with drier soils, comprises a scenario that is critical for survival of and colonization by ferns and lycophytes, since many of them are not adapted to exposure to drought or fire. In tropical forests, the climate outside of the forest is more severe than the climate in its interior, and therefore, leaf fall is considerably increased as compared with that in the interior (Lovejoy et al. 1986; Williams-Linera 1990; Vasconcelos \& Luizão 2004). 


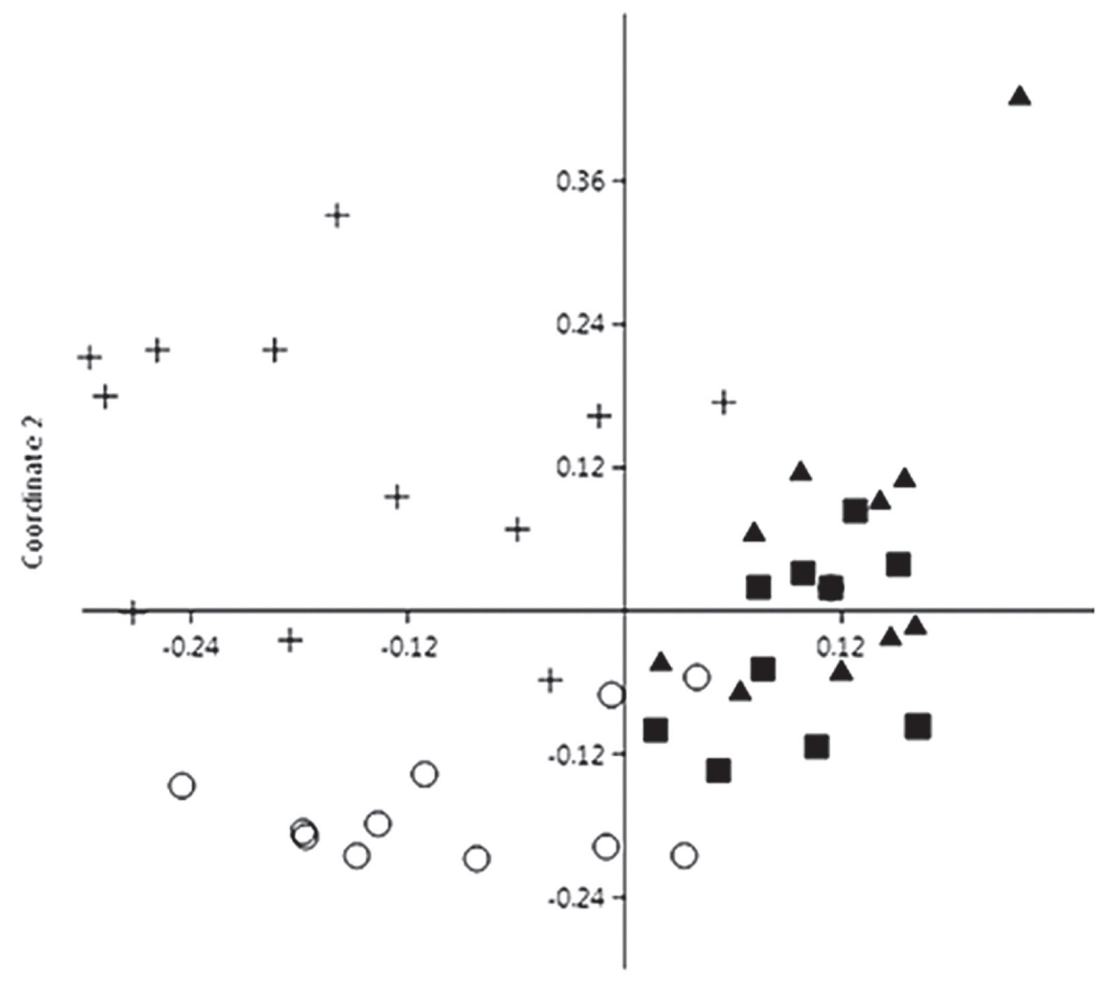

Coordinate 1

Figure 1. Principal coordinates analysis ( $\mathrm{PCoA})$ of sample plots at the edge and in the interior of the Macaco Branco and Cravina sites. Interior of Macaco Branco $(+)$, Edge of Macaco Branco (o), interior of Cravina (•), and edge of Cravina ( $\mathbf{(})$

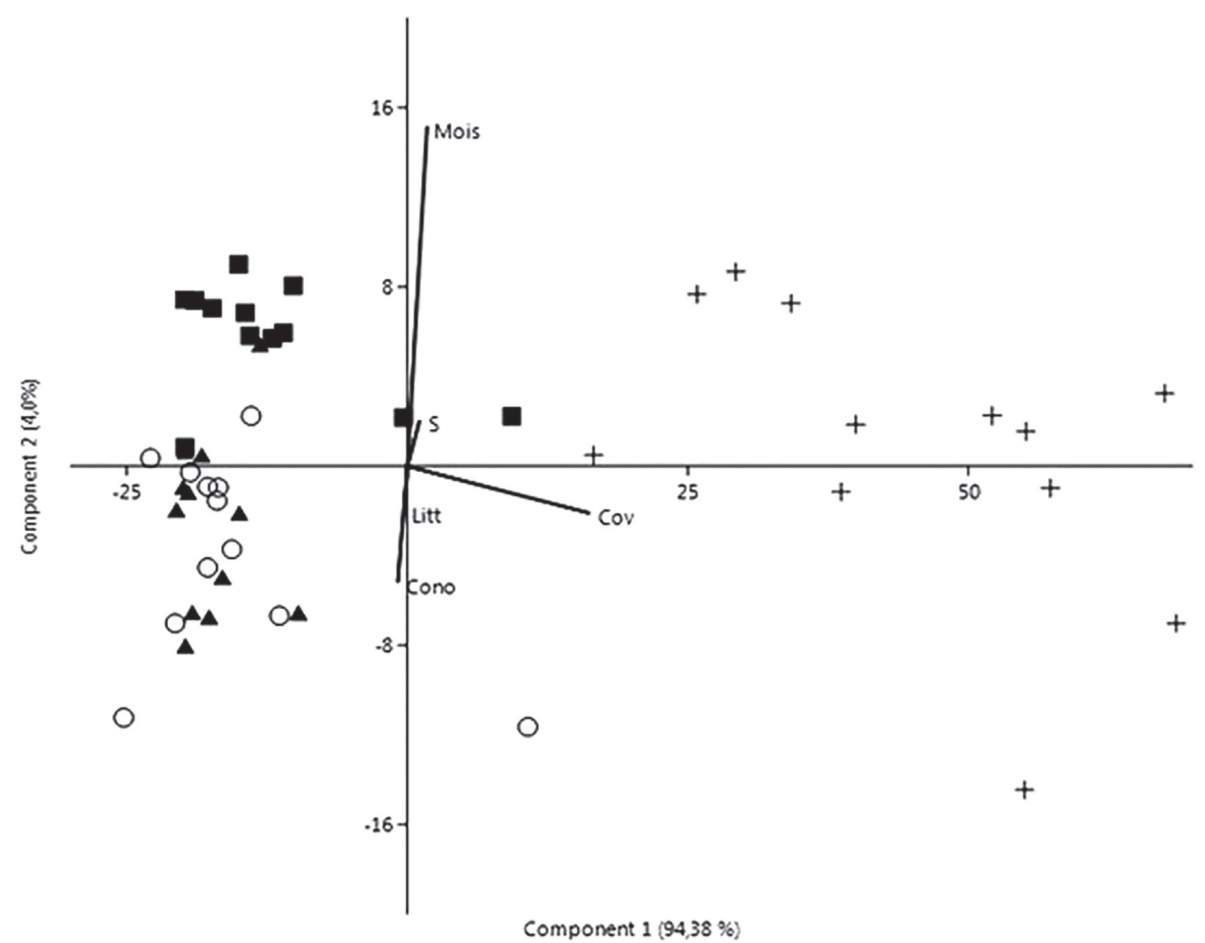

Figure 2. Principal components analysis (PCA) of sample plots at the edges and in the interiors of the Macaco Branco and Cravina sites. Interior of Macaco Branco $(+)$, edge at Macaco Branco (o), interior of Cravina ( $\bullet$ ), edge at Cravina $(\mathbf{\Delta})$, and their relationships with the variables (CONO: percent of open canopy area; COV: percent coverage of ferns and lycophytes; LITT: litter; MOIS: moisture content of soil; S: richness of ferns and lycophytes) 
Forest edges are more exposed, with more open vegetation, which allows greater penetration of winds, and as a consequence, reduces relative air humidity (Murcia 1995), as observed for the Cravina site. The same was not true of the Macaco Branco site because of the small distance from the edge to the next adjacent forest fragment, since they are only separated by a road passing through the conservation unit. In this case, the configuration of the surrounding vegetation may have worked as a barrier that buffered some of edge-mediated changes in the environmental factors. This fact is also related to a higher total species of ferns and lycophytes recorded in the Macaco Branco edge compared with Cravina, indicating that the isolation edges influence the species richness and climatic variables in different ways. However, Paciencia \& Prado (2004) observed that the amount of proximal edges and relatively open areas does not appear to influence the richness of ferns and lycophytes in Atlantic forest fragments in northeastern Brazil.

The temperature data recorded in this study did not vary significantly between the edge and the interior at both sites. In contrast, in a remnant of Atlantic rainforest in northeastern Brazil, other authors observed that temperatures were higher at forest edges (Silva et al. 2011). Although some authors (Lovejoy et al. 1986; Kapos 1989; Murcia 1995; Laurance 1997) suggest that air temperature is one of the most decisive factors for edge effects to occur, evidence to support this fact was not found in this study. Other factors, such as wind velocity, air humidity, soil moisture content, litter deposition, and canopy cover, proved to be more closely linked to the distribution of plants between the edge and interior of the Araucaria forest.

The generalized occurrence of some species, both at the edges and in the interiors, shows that they are more tolerant to varying levels of humidity, light intensity, and soil compositions. Among the species found in the current study, only Blechnum acutum and Dicksonia sellowiana accounted for over $66 \%$ of the total coverage of ferns and lycophytes. B. acutum is a neotropical element of rainforests (Brade 1942) and occurs in Araucaria forests with very high absolute frequency (Senna \& Waechter 1997). D. sellowiana is also considered a characteristic element of Araucaria forest, with leaves approximately $2.40 \mathrm{~m}$ in length (Fernandes 2000), favoring its coverage over large areas. The changes caused by forest edges eliminate species that are less tolerant to environmental change, altering the characteristic composition of the fern and lycophyte community and increasing the number of species that are restricted to the more-preserved forest interior. However, five species were exclusive to forest edges (Tab. 1), suggesting that the effects of fragmentation can restrict the development of some species while concurrently favoring the success of others that are adapted to the new conditions. In Araucaria forest exposed to cattle pasture, Fontoura et al. (2006) did not record terrestrial ferns up to $50 \mathrm{~m}$ away from the edge.
Although the two forest edge sites have different configurations in terms of the surrounding matrix, there were similarities between them in several of the variables analyzed (soil moisture, temperature, litter depth, coverage, and terrestrial species richness). Despite the fact that the forest edge at the Macaco Branco site is within a conservation unit and is formed by a road with occasional traffic of vehicles and people, a significant detrimental effect on species richness was still observed, in comparison with the interior at the same site. There is an evident need to implement strategies to mitigate the effects of roads inside conservation units. The greater the number of such roads, the greater the likelihood of edge effects to occur, and depending on the number of roads, many conservation units may be completely exposed to edge effects.

\section{Acknowledgements}

We thank Universidade Feevale for making available the infrastructure needed to accomplish this research; Dr. Maria Angelica Kieling-Rubio for their help in botanical identifications; Coordenação de Aperfeiçoamento de Pessoal de Nível Superior (CAPES) for the scholarship awarded to the first author, and the employees at the Floresta Nacional de São Francisco de Paula (FLONA-SFP) for the logistical support.

\section{References}

Baldwin LK, Bradfield GE. 2007. Bryophyte responses to fragmentation in temperate coastal rainforest: a functional approach. Biological Conservation 136: 408-422.

Barros ICL, Santiago ACP, Pereira AFN, Pietrobom MR. 2006. Pteridófitas. In: Pôrto KC, Almeida-Cortez JS, Tabarelli M. (eds.) Diversidade Biológica e Conservação da Floresta Atlântica a Norte do Rio São Francisco. Brasília, Ministério do Meio Ambiente. p. 148-171.

Bierregaard RO, Lovejoy TE, Kapos V, Santos AA, Hutchings RW. 1992. The Biological Dynamics of Tropical Rainforest Fragments: A prospective comparison of fragments and continuous forest. BioScience 42: $859-866$

Brade AC. 1942. A composição da flora pteridófita do Itatiaia. Rodriguésia 6: $29-43$.

Esseen P, Renhorn K. 1998. Edge effects on an epiphytic lichen in fragmented forests. Conservation Biology 12: 1307-1317.

Fahrig L. 2003. Effects of habitat fragmentation on biodiversity. Annual Review of Ecology, Evolution, and Systematics 34: 487-515.

Fernandes I. 2000. Taxonomia dos representantes de Dicksoniaceae no Brasil. Pesquisas Botânica 50: 5-26.

Ferrer-Castán D, Vetaas OR. 2005. Pteridophyte richness climate and topography in the Iberian Peninsula: comparing spatial and nonspatial models of richness patterns. Global Ecology and Biogeography 14: 155-165.

Fontoura SB, Ganade G, Larocca J. 2006. Changes in plant community diversity and composition across an edge between Araucaria forest and pasture in South Brazil. Revista Brasileira de Botânica 29: 79-91.

Forzza RC, Baumgratz JFA, Bicudo CEM, et al. 2012. New Brazilian floristic list highlights conservation challenges. BioScience 62: 39-45.

Frazer GW, Canham CD, Lertzman KP. 1999. Gap Light Analyzer (GLA): Imaging software to extract canopy structure and gap light transmission indices from truecolour fisheye photographs, user's manual and program documentation. New York, Simon Fraser University, Burnaby, British Columbia, and the Institute of Ecosystem Studies, Millbrook. 
Garcia LC, Rezende MQ, Pimenta MA, Machado RM, Lemos-Filho JP. 2007. Heterogeneidade do dossel e quantidade de luz no recrutamento do subbosque de uma mata ciliar no Alto São Francisco, Minas Gerais: análise através de fotos hemisféricas. Revista Brasileira de Biociências 5: 99-101.

Grime JP. 1985. Towards a functional description of vegetation. In: White J. (ed.) The Population Structure of Vegetation. Junk, Dordrecht, The Netherlands. p. 503- 514.

Hammer $\varnothing$, Harper DAT, Ryan PD. 2001. PAST: Paleontological Statistics package for education and data analysis. Paleontologia Electronica 4: 1-9. http://folk.uio.no/ohammer/past/.

Kapos V. 1989 Effects of isolation on the water status of forest patches in the Brazilian Amazon. Journal of Tropical Ecology 5: 173-185.

Laurance WF. 1997. Hyper-disturbed parks: edge effects and the ecology of isolated rain forest reserves in tropical Australia. In: Laurance WF, Bierregaard RO. (eds.) Tropical Forest Remnants: Ecology, Management, and Conservation of Fragmented Landscape. University of Chicago Press, Chicago. p. 71-83.

Laurance WF, Delamônica P, Laurance SG, Vasconcelos HL, Lovejoy TE. 2000. Rainforest fragmentation kills big trees. Nature 404: 836.

Laurance WF, Ferreira LV, Rankin-De Merona JM, Laurance SG, Hutchings R, Lovejoy TE. 1998. Effects of forest fragmentation on recruitment patterns in Amazonian tree communities. Conservation Biology 12: 460-464.

Laurance WF, Lovejoy TE, Vasconcelos HL, et al. 2002. Ecosystem decay of Amazonian Forest Fragments: a 22-Year Investigation. Conservation Biology 16: 605-618.

Lovejoy TE, Bierregaard RO, Rylands AB, et al. 1986. Edge and other effects of isolation on Amazon forest fragments. In: Soulé ME. (ed.). Conservation Biology: The Science of Scarcity and Diversity. Sinauer, Sunderland, Massachusetts. p. 257-285.

Metzger JP. 1999. Estrutura da paisagem e fragmentação: análise bibliográfica. Anais da Academia Brasileira de Ciências 71: 445-462.

MMA/SBF - Ministério do Meio Ambiente/Secretaria de Biodiversidade e Florestas. 2002. Avaliação e identificação de áreas e ações prioritárias para a conservação, utilização sustentável e repartição dos benefícios da biodiversidade nos biomas brasileiros. Brasília, MMA/SBF.

Moreno JA. 1961. Clima do Rio Grande do Sul. Porto Alegre, Secretaria da Agricultura.

Murcia C. 1995. Edge effects in fragmented forests: implications for conservation. Trends in Ecology and Evolution 10: 58-62.

Paciencia MLB, Prado J. 2004. Efeitos de borda sobre a comunidade de pteridófitas na Mata Atlântica da região de Una, sul da Bahia, Brasil. Revista Brasileira de Botânica 27: 641-653.

Paciencia MLB, Prado J. 2005. Effects of forest fragmentation on pteridophyte diversity in a tropical rain forest in Brazil. Plant Ecology 180: $87-104$

Pereira AFN, Silva IAA, Santiago ACP, Barros ICL. 2014. Efeito de borda sobre a comunidade de samambaias em fragmento de floresta atlântica (Bonito, Pernambuco, Brasil). Interciência 39: 281-287.
Portela RCQ, Santos FAM. 2007. Produção e espessura da serapilheira na borda e interior de fragmentos florestais de Mata Atlântica de diferentes tamanhos. Revista Brasileira de Botânica 30: 271-280.

Ribeiro MC, Metzger JP, Martensen AC, Ponzoni FJ, Hirota MM. 2009. The Brazilian Atlantic Forest: How much is left, and how is the remaining forest distributed? Implications for conservation. Biological Conservation 142: 1141-1153.

Senna RM, Kazmirczak C. 1997. Pteridófitas de um remanescente florestal no Morro da Extrema, Porto Alegre, RS. Revista da Faculdade Zootecnia, Veterinária e Agronomia 4: 47-57.

Senna RM, Waechter JL. 1997. Pteridófitas de uma floresta com araucária. Formas biológicas e padrões de distribuição geográfica. Iheringia, Série Botânica 48: 41-58.

Sharpe JM, Mehltreter K. 2010. Ecological insights from fern population dynamics. In: Mehltreter K, Walker LR, Sharpe JM. (eds.) Fern Ecology. Cambridge, Cambridge University Press. p. 61-110.

Silva IAA, Pereira AFN, Barros ICL. 2011. Edge effects on fern community in an Atlantic Forest remnant of Rio Formoso, PE, Brazil. Brazilian Journal of Biology 71: 421-430.

Silva IAA, Pereira AFN, Barros ICL. 2014. Fragmentation and loss of habitat: consequences for the fern communities in Atlantic forest remnants in Alagoas, north-eastern Brazil. Plant Ecology \& Diversity 7: 1-9.

Silva MM, Ganade G, Backes A. 2010. Regeneração natural em um remanescente de floresta ombrófila mista, na Floresta Nacional de São Francisco de Paula, Rio Grande do Sul, Brasil. Pesquisas Botânica 61: 259-278.

Smith AR, Pryer KM, Schuettpelz E, Korall P, Schneider H, Wolf PG. 2006 A classification for extant ferns. Taxon 55: 705-731.

Smith AR, Pryer KM, Schuettpelz E, Korall P, Schneider H, Wolf PG. 2008. Fern classification. In: Ranker TA, Haufler CH. (eds.) Biology and evolution of ferns and lycophytes. New York, Cambridge University Press. p. 417-467.

Streck EV, Kampf N, Dalmolin RSD, et al. 2008. Solos do Rio Grande do Sul. 2nd. edn. Porto Alegre, EMATER-RS.

Tabarelli M, Mantovani W, Peres CA. 1999. Effects of habitat fragmentation on plant guild structure in the montane Atlantic forest of southeastern Brazil. Biological Conservation 91: 119-127.

Vasconcelos HL, Luizão FJ. 2004. Litter Production and litter nutrient concentrations in a fragmented amazonian landscape. Ecological Applications 14: 884-892.

Turner IM. 1996. Species loss in fragments of tropical rain forest: a review of the evidence. Journal of Applied Ecology 33: 200-209.

Williams-Linera G. 1990. Vegetation structure and environmental conditions of forest edges in Panama. Journal of Ecology 78: 356-373.

Windisch PG. 1992. Pteridófitas da região norte-ocidental do Estado de São Paulo: Guia para estudo e excursões. 2nd. edn. São José do Rio Preto, UNESP. 